\title{
The Use of Simulation in Continuing Professional Development: A Comparison of Family Physicians' Awareness in Mersin and in Ann-Arbor
}

\author{
Sürekli Mesleki Gelişimde Simülasyon Kullanımı: Mersin ve Ann-Arbor Aile \\ Hekimlerinin Farkındalığının Karşılaştırılması \\ Ibrahim Bashan *1, Deborah Moulton Rooney ${ }^{2}$, James Matthew Cooke ${ }^{3}$
}

\begin{abstract}
ÖZET
Giriş: Türkiye'de, Sürekli Mesleki Gelişim (SMG) de simülasyon kullanımını teşvik etmek amacıyla, Türkiye'nin Mersin ilindeki aile hekimleri ile Amerika'nın Ann-Arbor bölgesindeki aile hekimlerinin eğitimlerinde simülasyon kullanımının, hangi eğitim metodlarında ve konu alanlarında fayda sağlayabileceğini belirlemek için SMG programlarında simülasyon ve kaynak kullanım alışkanlıkları araştıııldı. Yöntem: Mersin (MAHDER) ve Ann-Arbor (AFMRD) aile hekimleri derneklerine mail yoluyla değerlendirme anketleri gönderildi. Katılımcıların tamamladıkları anket, demografik verileri ve üç alanı kapsayan (SMG sebepleri, tercih edilen kaynaklar, öğrenim modaliteleri) 5 lik skalada değerlendirilen $(5=$ en yüksek) 10 soruluk 2 kısımdan oluşmuştu. Katılımcıların ülke, cinsiyet, ve kariyerlerine göre temel faktörler ve puanlama farklılıkları many-facet Rasch tekniği kullanılarak değerlendirildi. Bulgular: 273 aile hekimi anketi tamamladı. Mersin ve Ann-Arbor daki aile hekimlerinin herikisi için de, SMG'ye katılımda en önemli faktör "yeni şeyleri denemeye isteklilik" idi. "Simulasyon temelli eğitimi" bir öğrenme şekli olarak, Mersin'deki aile hekimleri, "Ann-Arbor" daki aile hekimlerine göre daha önemli bulduklarını, ancak SMG'de daha az kullandıklarını belirttiler. Diğer sonuçlar ve uygulamalar tartışıldı. Sonuç: Bu bulgular, Mersin'deki aile hekimlerinin SMG'de simulasyon kullanımının önemli bir eğitim şekli olduğunun farkında olduklarını ancak yaygın olarak kullanmadıkların göstermiştir. $\mathrm{Bu}$ durum Mersin'deki ve diğer gelişmekte olan ülkelerdeki aile hekimlerine yönelik yeni, simülasyona dayalı SMG müfredatının geliştirilmesi için firsatlar olduğunu önermektedir.
\end{abstract}

Anahtar kelimeler: Simulasyon, SMG, aile hekimliği

\begin{abstract}
Introduction: With the intent to promote using simulation in Continued Professional Development (CPD) in Turkey, we examined Turkish Family Medicines (FM) in Mersin and United States FMs in Ann-Arbor attitudes toward simulation and resources used in CPD programs to identify preferred teaching methods and subject areas that might benefit from the use of simulation for training. Method: A survey-based needs assessment was disseminated via email to FM Associations in Mersin (MAHDER) and in AnnArbor (AFMRD). Participants completed the 2-part survey that included demographics and 10 items across three domains (reasons for $\mathrm{CPD}$, preferred resources, learning modalities) rated on 5-point rating scales (5=highest). Top factors and rating differences across participants' country, gender, stage in career, were evaluated using a many-facet Rasch model. Results: Two-hundred, seventy-three FMs completed the survey. Top reason for participation in CPD was "Willingness to try new things" for both FMs in Mersin and Ann-Arbor. FMs in Mersin indicated "Simulation-based training" had higher importance as a learning modality than FMs in Ann-Arbor, but reported less use of simulation for CPD. Other detailed findings and their implications are discussed. Conclusions: Findings suggest that FMs in Mersin feel that simulation is an important educational modality for CPD but it is not widely employed. This suggests that there are opportunities for the development of novel, simulation-based CPD curricula targeted to FM physicians in Mersin. with potential expansion to other developing countries.
\end{abstract}

Key words: Simulation, CPD, family medicine

Received / Geliş tarihi: 28.01.2017, Accepted / Kabul tarihi: 14.02.2017

${ }^{1}$ Department of Medical Education, Faculty of Medicine, University of Mersin

${ }^{2}$ Department of Learning Health Sciences, Faculty of Medicine, University of Michigan

${ }^{3}$ Departments of Family Medicine and Learning Health Sciences, Faculty of Medicine, University of Michigan

*Address for Correspondence / Yazışma Adresi: İbrahim Başhan. Department of Medical Education, Faculty of Medicine, University of MersinTurkey, E-mail: ibashan@yahoo.com

Bashan I, Rooney DM, Cooke JM. The Use of Simulation in Continuing Professional Development: A Comparison of Family Physicians' Awareness in Mersin and in Ann-Arbor, TJFMPC, 2017;11(1): 29-37.

DOI: $10.21763 /$ tjfmpc. 295812 


\section{INTRODUCTION}

Over the past two decades, there has been an exponential and enthusiastic adoption of simulation in healthcare education world-wide, with a focus in undergraduate and gradual educational programs. Increased demands on teaching faculty, expanding content, increased focus on patient safety and the increased technical expertise and expectation of students have led to a new paradigm of education in healthcare that increasingly involves technology and innovative ways to provide a standard curricula. Simulation using is rising in medical education to teach cognitive, psychomotor, and affective skills to individuals and groups, also allows for training in a controlled environment, with opportunities for planned practice and assessment for family medicines and also for all of the physicians. ${ }^{1}$

Medical education in Turkey has a rich history. Currently, there are over 60 Medical Schools in Turkey, yet, most of them lack clinical simulation centers. Over the last decade, there has been increased interest in simulation, and some Turkish medical training programs have implemented simulation-based education, although the paucity of available literature indicates simulation is yet to be commonly practiced. Clinical simulation applications are being used for the purpose of improving the technical skills of students, residents and even trainers at private Universities. $^{2-5}$ Simulation-based programs have also been adapted for training practicing physicians of hospital-based Emergency and Anaesthesiology departments, and adapted for in-house training on CPR (Cardiopulmonary Resuscitation). ${ }^{6}$ In spite of some interest in employing simulation-based training applications within Turkish academic medical centers for the benefit of basic and postgraduate medical programs, simulation-based training has not extended to continuing professional development programs.

CPD spans the period following basic medical and post-graduate training and continues throughout a doctor's professional career. ${ }^{7} \mathrm{CPD}$ primarily focuses on three key points; life-long learning, continuous performance improvement, and qualifications lasting throughout the career, 8,9 and is a critical tool for maintaining best practices in patient care across a nation's healthcare system. ${ }^{10,11}$ CPD prioritizes self-directed learning, professional self-awareness, learning developed in context, multidisciplinary and multilevel cooperation, and an inquiry-based concept of professionalism. It also promotes physicians' awareness and accountability to patients, the community, managers and administrators, and often includes assessment which is internal, participatory and cooperative rather than external and objective. ${ }^{12}$

Many countries are now moving from a 'knowledge and skills based' CPD system, towards a system that promotes lifelong learning and continuous professional development. ${ }^{13}$ For example, the United Kingdom Department of Health identifies CPD as a way of maintaining standards of care, improving the health of the public, and hiring, motivating, and keeping high quality staff. ${ }^{14}$ The national Canadian guide to essential physician skills for optimal patient safety, the CanMEDS Physician Competency Framework, encompasses such CPD subjects as doctor-patient communication, multidisciplinary team skills and risk management, all of which are considered "Skills for the New Millennium". ${ }^{15}$ In spite of growing interest in CPD, there has been tremendous debate regarding the value of continuing medical education programs. Most concerns surround the potential bias and influence pharmaceutical and medical equipment suppliers may have on medical decision making. ${ }^{16,17}$ Ineffective CPD may account for the misalignment between evidence and practice and, perhaps, create significant delays between publication of evidence and change in standard of care. In Turkey, the Turkish Medical Association (TMA) has worked for a number of years to improve the quality of continuing professional education, and with that intent, has formed the Continuing Medical Education Accrediation Committee (CMEAC) to raise the perceived value and appeal of CPD activities for Turkish physicians. ${ }^{18}$ In order to identify the preferred CPD tools and techniques for the dissemination of best clinical practices is critical to improving CPD. In this context, it is important to gauge medical professionals' opinions toward the professional development practices. Inquiry may also help gain a deeper understanding of learners' motivation for, and preferred resources used in, their own professional development. Using this information, we might develop more engaging curricula that are better targeted to medical professionals' training needs. 
Following a professional exchange program between Turkish and US physicians and medical education experts, authors from the two countries wished to gain a better understanding of family medicine physicians' educational needs, interests and use of simulation due to its adoption by other professional organizations for CPD. Despite many differences in medical practice identified through the exchange, most notably the significantly higher daily patient volume in Turkey and significantly higher documentation and regulatory requirements in the US, CPD needs were thought to be similar based on the common need for accurate and rapid data gathering, physical examination, medical decision making and coordination of care. The survey and analysis focussed on three domains;

a) Why family physicians participate in continuing professional development,

b) What preferences exist for CPD, and

c) Whether simulation is a viable option for CPD among practicing physicians.

\section{METHOD}

\section{Study Design}

Following exempt determination by University of Michigan's Institutional Review Board, we performed a needs assessment across two Family Medicine Associations in Mersin-Turkey and AnnArbor-US. In independent but parallel studies, participants were recruited via the American Family Medicine Residency Directors (AFMRD) listserv in Ann-Arbor, and mass email via the Association of Family Physicians Association in Mersin (MAHDER).

The survey (Appendix A) consisted of two parts. Part I included five demographics questions, including participant's gender, age (a proxy for stage in career), professional role and specialty training. Part II consisted of two questions used to identify reasons for participating in CPD and preferred topics (with prompts to "select all that apply"), one question about the importance of learning modalities for CPD [rated from 1 (not important) to 5 (most important)], and additional four questions regarding continuing professional development, where participants were asked to rate their level of agreement with each statement using 5-point Likert rating scales ranging from 1 (strongly disagree) to 5 (strongly agree).

\section{Statistical analysis}

We summarize demographic information, reasons for participating in, and preferred topics in CPD, as frequencies. We analysed rating differences across participants' country, gender, stage in career, and self-reported simulation participation level using the many-facet Rasch model which is a psychometric model for analyzing categorical data, such as answers to questions on a reading assessment or questionnaire responses, as a function of the trade-off between the respondent's abilities, attitudes or personality traits and the item difficulty. ${ }^{19}$ Analyses were performed using the Facets Software, v3.68.2. ${ }^{20}$

\section{RESULTS}

A total of 276 participants completed the survey. With a response rates of $26.3 \%$ and $9.7 \%$, in Mersin and Ann-Arbor, respectively. 208 FMs from Mersin in Turkey and 68 FMs from Ann-Arbor in US participated. Demographic information is displayed in Table 1.

The majority of Turkish participants selfidentified as general practitioner, while the majority of US participants were FMs. Mean participant ages were 39.3 and 46.3 years old for Turkish and US participants, respectively. The majority of all participants $(89.9 \%)$ were early- to mid-career physicians.

Additionally, US FMs in Ann-Arbor had more experience in simulation-based education for CPD, with a majority (54\%) self-reporting their experience as Sometimes or Often. Fewer Turkish participants in Mersin (24\%) self-reported their simulation-based experience in these higher categories, while $26 \%$ and $38 \%$ of US and Turkish participating FMs reported no simulation-based education experiences in CPD, respectively. Why do FMs Participate in CPD?

As summarized in Figure 1, when asked why physicians participate in CPD, physicians' top two rated reasons were "Willingness to try new things," [Mersin, $\mathrm{n}=165$ (79\%), Ann-Arbor, $\mathrm{n}=63$ $(95 \%)]$ and "Training to provide a new service/procedure," [Mersin, $\mathrm{n}=154(74 \%)$, AnnArbor, $\mathrm{n}=45(68 \%)]$.

"Employment requirement" was the least endorsed reason to participate in CPD for Turkish FMs in Mersin Relatively few Turkish FMs [38 $(18 \%)]$ selected this reason when compared to 38 (58\%) of US FMs in Ann-Arbor. Inversely, "Extra income" was the least endorsed reason to participate in CPD for US FMs. Relatively few US FMs in Ann-Arbor $5(8 \%)$ selected this reason when compared to 79 (38\%) of Turkish FMs in Ann-Arbor. Six (3\%) of Turkish physicians added "Other" reasons to engage in CPD, including "to remember medical knowledge that I don't use frequently," "to be notified of updated applications, "adapting to change," and "to network 
with other health professionals." 9 (14\%) US

me sharp as a teacher," "desire for respondents' added similar reasons included "keeps

Table 1. Summary of participant characteristics by country

Mersin

$n=208$
Ann-Arbor

$n=68$

Characteristic

$125(60 \%)$

$30(44 \%)$

Male

Female

$85(40 \%)$

$35(52 \%)$

Undesignated

$3(4 \%)$

Age (years)

$\begin{array}{lcc}\text { Mean Age } & 39.3(7.9) & 46.3(12.6) \\ \text { Early (<34) } & 56(27 \%) & 8(12 \%) \\ \text { Early-Mid (35-44) } & 90(43 \%) & 23(34 \%) \\ \text { Mid (45-54) } & 58(28 \%) & 13(19 \%) \\ \text { Mid-Late (55-64) } & 4(2 \%) & 16(23 \%) \\ \text { Late (>65) } & - & 2(3 \%) \\ \text { Undesignated } & - & 6(9 \%)\end{array}$

Professional Role

Family Medicine Resident

Family Medicine Physician

Family Medicine Academic

Family Medicine Specialist

General Practitioner

Undesignated
$25(12 \%)$

$30(44 \%)$

$7(3 \%)$

$19(9 \%)$

$15(22 \%)$

$157(76 \%)$

$\begin{array}{ll}- & 23(34 \%)\end{array}$ 


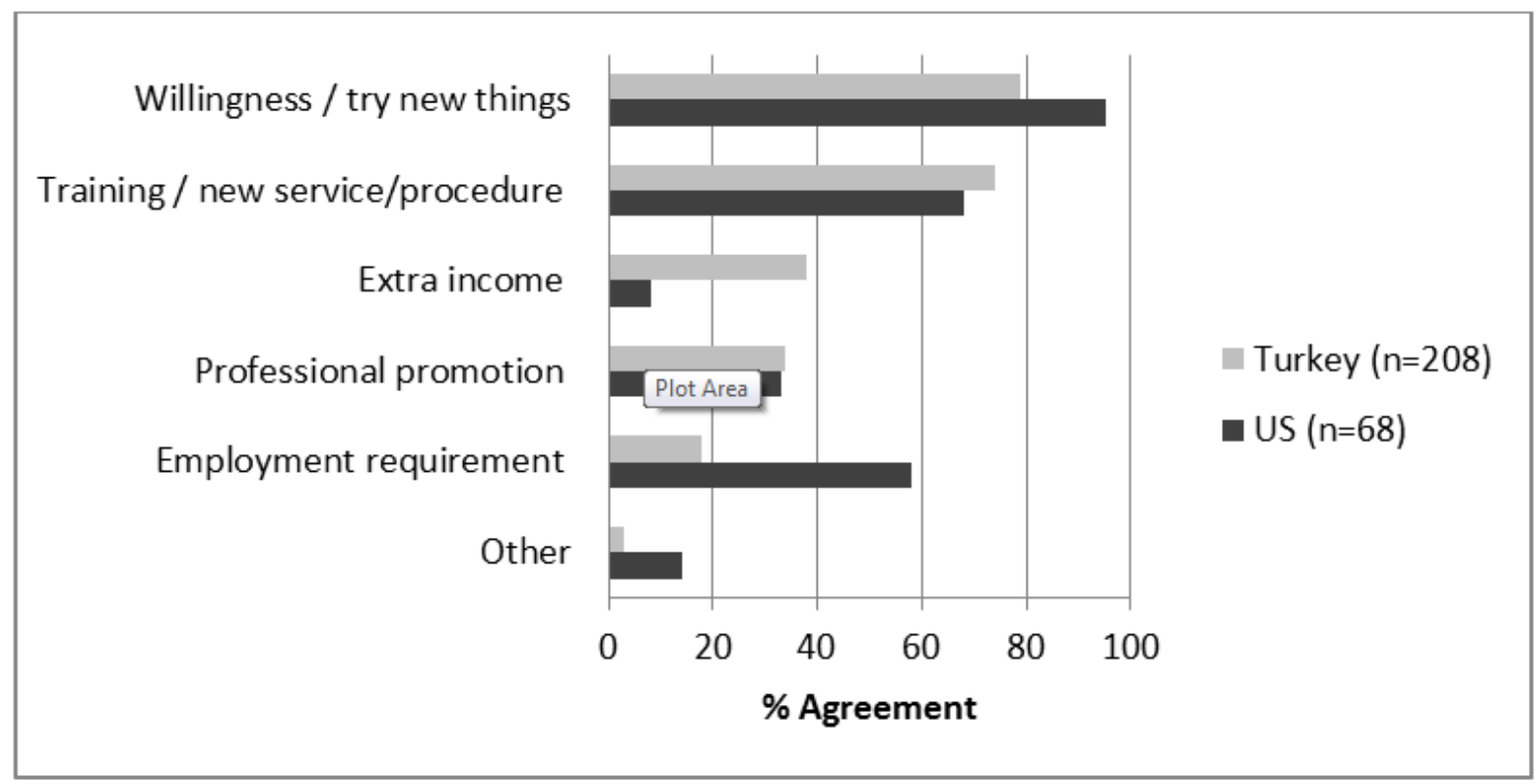

Figure 1. Mersin in Turkey and Ann-Arbor inUnited States FMs' reasons to engage in CPD by frequency

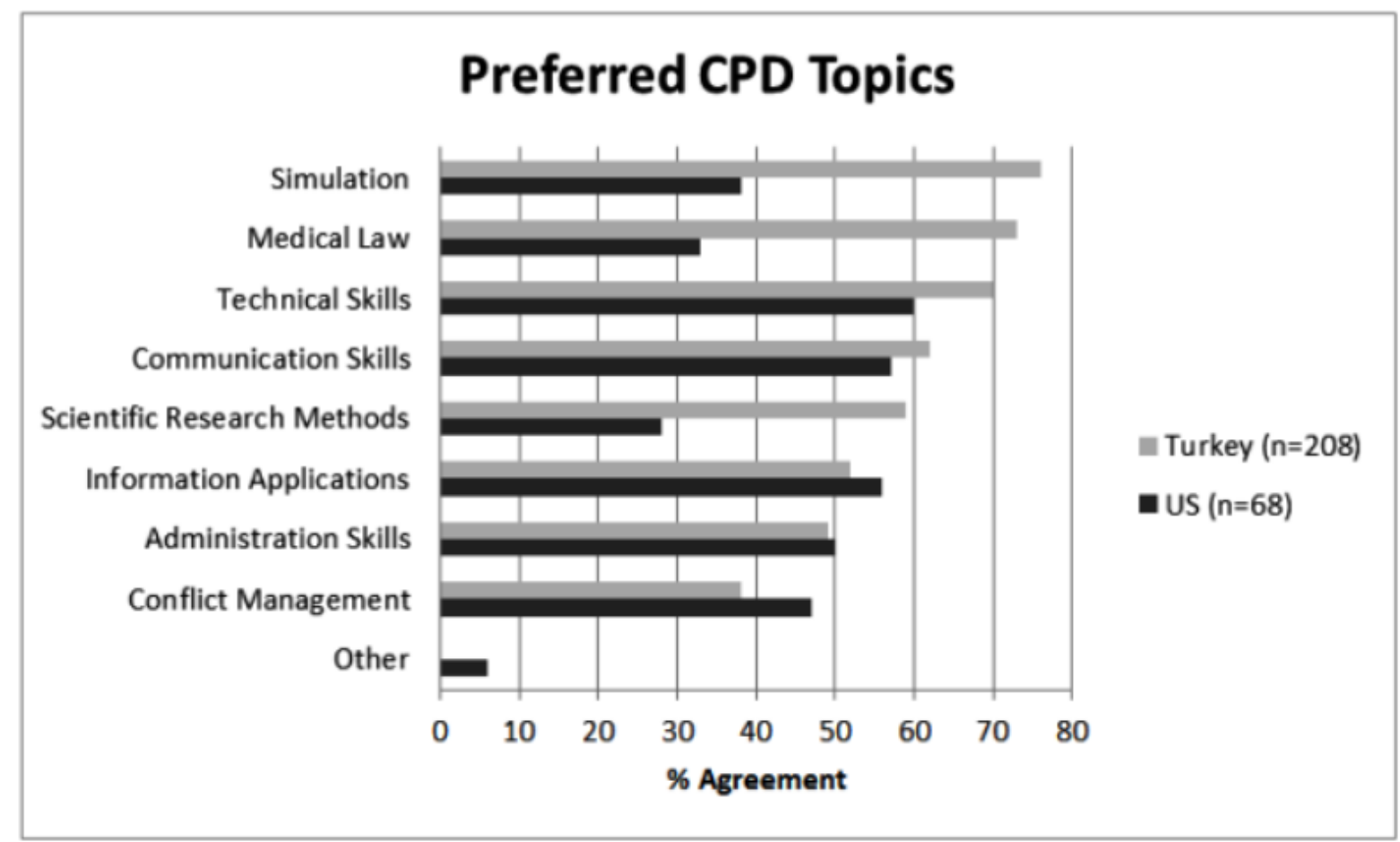

Figure 2. Mersin in Turkey and Ann-Arbor inUnited States FMs' preferred CPD topics 
excellence," and "ability to network with colleagues."

When reviewing differences across all participants' stage in career there were differences identified for two items, both $\mathrm{p}=.001$. For mid-tolate stage career FMs $(n=20$, age ranging from 55 to 64 , Mean $=60$ years old), $50 \%$ cited "Employment requirement" for reason to engage in CPD, while only $11.3 \%$ of all others $(n=256$, age ranging from 20 to 54 , Mean $=48$ years old) cited this as a reason, $\mathrm{p}=0.001$. Reflexively, only $11.7 \%$ of the mid-to-late stage career family physicians cited "Training to provide a new service/procedure" for a reason to engage in CPD, while $65 \%$ of all others cited this as a reason to engage in CPD.

Importance of CPD for professional proficiency. When participants were asked how important CPD was for professional proficiency, opinions varied across nationality. A higher percentage of Turkish participants believed that CPD is necessary for professional proficiency, with $64 \%$ participants endorsing Highly important or Most important, compared to US participants, where $17 \%$ of participants endorsed Highly important or Most important. $71 \%$ of US participants rated CPD Less important or Somewhat important for professional proficiency.

In spite of this difference, Turkish and US respondents did agree that receiving updates related to current best practices during CPD benefitted clinical practice with $90 \%$ of participants from both countries agreeing with Highly important or Most important.

\section{What are FMs Preferences Regarding CPD?}

Preferred Topics. When asked, which topics should be included in continuing professional development, there were differences in countries' preferences. The top three topics for Turkish respondents were "Simulation application in clinical education," "Medical law," and "Technical skills development" with at least 145 (70\%) participant selection for all. The top-rated topics for US respondents were "Technical skills development," "Communication skills," and Information management" with 49 (60\%), 39 (57\%) and $38(56 \%)$ respective selection rates (Figure 2).

The least preferred topic for Turkish participants was "Conflict management skills," with
$80(38 \%)$ Turkish FMs believing the topic should be included in CPD. The least preferred topic for US participants was "Scientific research methods" $(\mathrm{n}=19,28 \%)$.

Preferred Resources. When asked to rate the resources FMs used for their own continuing professional development, there were significant differences found across the two countries. Turkish participants indicated "Online Magazines/Books," "Meetings/ Courses/ Seminars," and "Specialist Opinion" were at least Sometimes used, with Mean ratings of 3.6, 3.4 and 3.3, respectively. US participants indicated "Clinical Simulation," "Web/Computer-based Simulation," and "Textbooks" were most utilized resources, and Often used, as with Mean ratings of 4.0, 3.8 and 3.5 , respectively (Table 2 ).

A small number of participants from Mersin $(n=4,2 \%)$ and Ann-Arbor $(n=6,9 \%)$ selfreported high levels of personal participating in simulation (Often or Mostly used). These participants, indicated statistically higher usage ratings for "Web/Computer-based simulation" ( $\mathrm{n}=$ $10, M=3.5, S D=0.7)$ than all other participants ( $\mathrm{n}$ $=263, \mathrm{M}=2.6, \mathrm{SD}=1.2), \mathrm{p}=0.01$. There were no other significant differences found for the resources used for CPD.

Preferred delivery mechanism. When asked to rate the importance of six delivery mechanisms employed in CPD, there was mixed agreement across countries. Turkish and US participants indicated "Simulation-based training" was at least Somewhat important, with mean ratings 3.3 and 3.9, respectively. In spite of this agreement about simulation, the countries' participants did not agree on the top-rated learning mechanism in CPD. Turkish physicians rated "Medical congress/ symposium" as the most important delivery mechanism [M = $3.9(0.8)]$, while US participants considered "Drug company meetings" as Most important $[\mathrm{M}=4.7(0.9)]$ (Table 3).

Preferred retraining frequency. When asked how often should CPD courses be repeated, there was reasonable agreement across countries, with largest percentage of Mersin FMs (59, 29\%) and Ann Arbor participants (25, 42\%) selecting "Every 2 years" as their preferred CPD frequency. 
Table 2. Comparison of Mersin and Ann-Arbor FMs use of resources used during CPD, scored on a 5point scale ( $1=$ none, $5=$ mostly).

Mersin
Mean (SD)
$(n=208)$

\author{
Ann-Arbor \\ Mean (SD) \\ $(n=68)$
}

P-value
Published periodical (magazine)

Textbooks

Online magazines/Books

Clinical simulation

Web/Computer-based simulation

Meetings/Courses/Seminars

Specialist opinion
$2.4(1.1)$

$2.5(1.2)$

$3.6(0.9)$

$2.6(1.1)$

$2.3(1.1)$

$3.4(1.0)$

$3.3(0.7)$
$2.3(0.8)$

0.52

$3.5(0.9)$

0.01

$2.5(0.9)$

0.01

$4.0(1.1)$

0.01

$3.8(1.3)$

0.01

$2.4(0.9)$

0.01

$2.9(0.9)$

0.01

Table 3. Comparison of Mersin and Ann-Arbor FMs' ratings of CPD delivery mechanisms, scored on 5point scale.

Delivery Mechanism

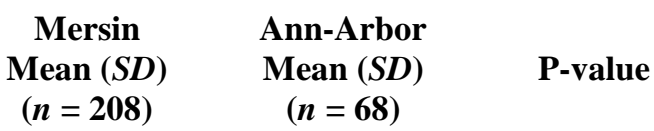

Simulation-based training

Medical congress/ Symposium

On-unit training

Conference

Web-based training

Drug company meetings

$\begin{array}{lll}3.9(0.91) & 3.3(1.00) & \text { n. s. } \\ 3.9(0.78) & 2.9(1.00) & 0.004 \\ 3.8(0.76) & 2.6(1.02) & 0.001 \\ 3.8(0.76) & 2.2(0.89) & 0.001 \\ 3.7(0.79) & 3.0(1.04) & 0.004 \\ 3.0(0.85) & 4.7(0.93) & 0.001\end{array}$

What are FMs Opinions toward Simulation in CPD?

When asked to rate their agreement with two statements, there was high agreement across countries. When asked to rate their agreement with the statement "Training programs that employ simulation applications are important for patient safety," Mersin and Ann Arbor participants' mean ratings were $4.1(\mathrm{SD}=0.89)$, and $3.9(\mathrm{SD}=1.18)$, respectively, both aligning with Highly important. Similarly, Mersin and Ann Arbor FMs thought "Clinical simulation should be included in CPD programs," with mean ratings of 3.9 ( $\mathrm{SD}=0.95)$, and 3.8 (SD $=0.99)$, respectively. No statistical differences were found across nationality, gender, or stage in career.

\section{DISCUSSION}


Findings from our work offer insights on FMs in Mersin and Ann-Arbor opinions toward CPD. We highlight findings from the three overarching domains, and the possible implications from these findings.

\section{Why do FMs Participate in CPD?}

Although participating physicians' motivation to engage in CPD seemed to be founded on their own willingness to try new things, there are differences to consider regarding motivators and incentives to engage in CPD. First, perceived value of CPD seemed to vary across nationality. The majority of Turkish FMs (64\%) felt that CPD was highly important for professional proficiency, while a majority of the US FMs (71\%) rated CPD as less important or somewhat important for professional proficiency. Second, stage in career seemed to influence FMs' motivation to engage in CPD, similar to Pool and colleagues' findings from their study of nurses' opinions toward CPD. ${ }^{21}$ Most notable, later stage physicians (> 55 years old) from both Mersin and Ann-Arbor cited "Employment requirement," while early-middle stage career physicians cited "Training to provide new service/procedure" as the top reason to engage in CPD, suggesting that some CPD curricular content and/or delivery methods could be better targeted to later-stage physicians to improve relevance and perhaps, overall value. Finally, our findings indicate that motivation to engage in CPD in Mersin could be tied to pay incentives, different from Ann Arbor, where CPD is an employment requirement.

\section{What are FMs Preferences Regarding CPD?}

Findings indicated Turkish FMs prefer to use conferences, peer-specialists, and web-accessed periodicals as resources, while US FMs prefer to use web-based and simulation-based resources. When reviewing differences across self-reported simulation participation levels, the few participants who self-reported higher level of simulation participation in CPD had higher ratings toward "Web/Computer-based simulation" than all other participants. They also reported their use of web/computer-based simulation higher than clinical simulation-based education. These ratings were not significantly different from those for less "simulation savvy" physicians, likely stemming from American Board of Family Medicine requirement for regular computer-based simulation, called Simulation Activity Modules or SAMs, that are linked to recurring Maintenance of Certification requirements. $^{22}$ This may also be due to the lack of skill-based clinical simulation activities available to family physicians for CPD. Regarding preferred delivery mechanism, Mersin FMs rated "Medical congress/ symposium" as the most important delivery mechanism, while Ann Arbor participants considered "Drug company meetings" as most important. Regardless of nationality, participants prefer "every 2 years" as their preferred CPD frequency.

\section{What are FMs Opinions toward Simulation in CPD?}

Turkish and US participants agreed that training programs that employ simulation applications are important for patient safety, and clinical simulation should be included in CPD programs. No statistical differences were found across nationality, gender, or stage in career.

There are limitations related to the inferences we make of the study's findings. First, in spite of our efforts at maximizing the sample by capturing data via nationally-recognized family medicine associations, the sample size was still relatively small. The associations targeted for the purpose of the survey sampled family physicians, residents and general practitioners in Mersin compared with family physician educators involved in residency education among the Ann Arbor cohort. This difference was also represented in the relatively older mean age and self-description as family physician specialist of Ann Arbor cohort compared with the younger and higher proportion of general practitioners among the Mersin cohort. Other differences may have included licensing and certification requirements, regional credentialing requirements and general educational expectations and traditions, but the sample was geographically broad enough to represent CPD perspectives and trends for the two countries. For the purpose of this study, the smaller sample size may not fully reflect the opinions of FMs in Mersin and Ann Arbor. Therefore, the inferences we make in this research are limited given the scope of the available evidence.

Despite the limitations, there are some telling themes with potential implications for CPD design. Although the evolving motivations to participate in CPD throughout the stages of a medical career is similar among FMs in Mersin and Ann Arbor, preferred resources and CPD delivery methods were significantly different, though skill-based and computer-based simulation were preferred methods by both groups.

With the mounting evidence for simulation as a superior method for knowledge, skill, behavior outcomes as well as a growing body of evidence for improved patient outcomes, both educational efficacy and desirability must be considered by those producing CPD programs and for certification and licensing bodies requiring CPD. As is the case 
with all education, understanding the goals or desired outcomes, understanding the audience, harnessing optimal delivery methods, utilizing selfassessment and continuous improvement of the intervention are all critical for long-term success.

Although the motivations to participate in CPD throughout the stages of a medical career was similar among the sampled FMs from Mersin and Ann Arbor, preferred resources and CPD delivery methods were significantly different. Capturing opinions of targeted physicians can improve our understanding of learners' targeted goals, desired outcomes, and preferred delivery methods. This knowledge can be used to apply readily-accepted best practices in CPD, and facilitate continuous improvement of CPD programs in Mersin and other developing countries.

\section{REFERENCES}

1. Motola I, Devine LA, Chung HS, Sullivan JE, Issenberg SB. Simulation in healthcare education: a best evidence practical guide. Med Teach 2013;35(10):1511-1530.

2. Kurdak H, Altintas D, Doran F. Medical education in Turkey: past to future. Med Teach 2008;30(8): 768-773.

3. World Federation for Medical Education (WFME) and For Advancement of International Medical Education and Research (FAIMER). https://search.wdoms.org/. Accessed September 23, 2015.

4. Description of simulators for medical learners. Acibadem http://case.acibadem.edu.tr/trUniversity. tr/Sayfalar/Mezuniyet-Oncesi.aspx. Accessed September 23, 2015.

5. Center of Advanced Simulation and Education (CASE). Acibadem University. http://case.acibadem.edu.tr/trtr/Sayfalar/Mezuniyet-Sonrasi.aspx. Accessed September 23, 2015.

6. Adult Basic and Advanced Life Support Applications.

http://birincibasamak.org/yazarlarimizdanhand anbirbicereristemileriyasdesApr2015tr.php.

Accessed September 23, 2015.

7. MacCarrick GR. A practical guide to using the World Federation for Medical Education (WFME) standards. WFME 1: mission and objectives. Ir J Med Sci 2010;179(4):483-487.

8. Karim SI, Irfan F, Qureshi R, Naeem N, Alfaris EA. Evaluation of continuing professional development pogram for family physicians. Pak J Med Sci 2013;29(2):458-463.

9. Basic Medical Education. World Federation for Medical Education (WFME) Global Standards for Quality Improvement. Copenhagen, 2003. http://www.wfme.org. Accessed March 11, 2008.

10. Brown CA, Belfield CR, Field SJ. Cost effectiveness of continuing professional development in health care: a critical review of the evidence. BMJ 2002;324:652-655.

11. François P. The via crucis of continuing professional development. Press Med. 2014;14:353-354.

12. Brigley S, Young Y, Littlejohns P, McEwen J. Continuing education for medical professionals: a reflective model. Postgrad Med J 1997; 73:23-26.

13. Murgatroyd G. Intelligence unit research. Continuing professional development, the international perspective. http://www.gmcuk.org/CPD_The_International _Perspective__Jul_11.pdf_44810902.pdf. Accessed November 11, 2015.

14. Department of Health. Our healthier nation: a contract for health. London. 1998. https://www.gov.uk/government/publications/o ur-healthier-nation-a-contract-forhealth.Accessed October 17, 2014.

15. The CanMEDS 2000 Project; Skills for the new millennium: report of the societal needs working group. The Royal College of Physicians and Surgeons of Canada's Canadian Medical Education Directions. https://www.surgeons.org/media/301671/canm eds_e.pdf. Accessed on November 11, 2015.

16. Davis D, Galbraith R. Continuing medical education effect on practice performance: effectiveness of continuing medical education: American college of chest physicians evidencebased educational guidelines. Chest 2009;135(3):42-48.

17. Marinopoulos SS, Dorman T, Ratanawongsa N, Wilson LM, Ashar BH, Magaziner JL, et al. Effectiveness of continuing medical education. Evid Rep Technol Assess 2007; 149:1-69.

18. Yaman H. Continuing medical education in Turkey: Recent developments. BMC Med Educ 2002; 19(2):6.

19. Rasch, G. Probabilistic models for some intelligence and attainment tests. Chicago, IL: The University of Chicago Press; 1980.

20. Linacre. JM. Facets ${ }^{\circledR}$ Many-Facet Rasch Measurement Software, version 3.67. Chicago, IL: MESA Press; 2010.

21. Pool IA, Poell RF, Berings MG, ten Cate O. Strategies for continuing professional development among younger, middle-aged, and older nurses: a biographical approach. Int J Nurs Stud 2015;52(5):939-950.

22. Description of American Board of Family Medicine Simulation Activity Modules. https://www.theabfm.org/moc/part2.aspx. Accessed October 22, 2015. 